\title{
Changes in Serum Protein and Enzyme Levels in Human T Lymphotropic Virus-1-Infected Patient
}

\author{
Amer Abdulrahman Almaiman \\ Department of Applied Medical Sciences, Community College of Unaizah, Qassim University, Qassim, Saudi Arabia
}

\begin{abstract}
This study aims to evaluate the changes in serum protein levels in a patient with confirmed human T lymphotropic virus type-1 (HTLV-1) infection. Screening and confirmation tests were performed for HTLV-1, along with an assessment of overall albumin, alpha 1 and 2, and gamma and beta globulin levels, using SAS-3 protein electrophoretic analysis. HTLV-1 positivity was confirmed with enzyme-linked immunosorbent assay (ELISA) and nucleic acid amplification testing (NAT). The biochemical tests or protein levels did not exhibit any changes in HTLV-1 infection, indicating that HTLV-1 results in a rare silent infection that does not result in changes in protein levels at the early stages. To aid early detection of the virus and initiate treatment, a comprehensive investigation at the protein and gene levels should be performed.
\end{abstract}

Key Words: HTLV-1, Serum proteins, SAS-3 electrophoretic analysis.

How to cite this article: Almaiman AA. Changes in Serum Protein and Enzyme Levels in Human T Lymphotropic Virus-1-Infected Patient. J Coll Physicians Surg Pak 2020; 30(10):1092-1095.

\section{INTRODUCTION}

The community of global blood banks has recognised blood safety related decision-making as a highly complex issue that cannot be managed easily. ${ }^{1}$ One of the challenges faced by blood banks is human T-lymphotropic virus type-1 (HTLV-1) infection. HTLV-1 is a human retrovirus that causes several health problems globally; and is considered a vital etiological agent for the very aggressive T-cell malignancy, adult T-cell leukaemia/lymphoma (ATL) and HTLV-associated myelopathy/tropical spastic paraparesis (HAM/TSP). ${ }^{1,2}$ The number of HTLV-1 infected people worldwide has been estimated at 5-10 million ${ }^{2}$. High prevalence rates of HTLV-1 have been reported in many countries, including India and Canada; ${ }^{3,4}$ whereas, Saudi Arabia and Kuwait display low prevalence rates. ${ }^{5,6}$

From the epidemiology point of view, three main routes of HTLV-1 transmission exist: breast-feeding, sexual intercourse, and contaminated blood transfusion. ${ }^{7}$ The estimated HTLV-1 transmission rate through contaminated blood component transfusion ranges between $27 \%$ and $63 \%^{7}$. Screening for HTLV- 1 in blood donors is mandatory in Saudi Arabia, despite the fact that its prevalence is low and the procedure is costly.

Correspondence to: Dr. Amer Abdulrahman Almaiman, Department of Applied Medical Sciences, Community College of Unaizah, Qassim University, Qassim, Saudi Arabia

E-mail: ameralmeman@hotmail.com

Received: June 20, 2019; Revised: November 08, 2019;

Accepted: December 09, 2019

DOI: https://doi.org/10.29271/jcpsp.2020.10.1092
More than 9,460 screened donors in the years 2013 - 2017 revealed nine HTLV-1-positive cases and there were no reactive donors from 107,419 donations during 2006-2016.,

Several studies have shown that HTLV-1 infection leads to changes in the levels of some proteins. ${ }^{1,9,10}$ Therefore, this study was conducted to evaluate some biomarkers (haematological, biochemical, and serological) in an HTLV-1-positive donor, which could be used for early HTLV-1 detection.

\section{CASE REPORT}

A 34-year man visited hospital's blood bank for blood donation. He was a regular blood donor, donating every 6 months, for more than 5 years.

The Research Ethics Committee (No. 1378176) approved this case study. The blood pressure, haemoglobin level, and antibody screen etc., of the donor were all normal. A blood sample was obtained and subjected to initial screening for transfusion-transmitted infections (TT/s). The tests were negative for viruses, including hepatitis B (HBV), hepatitis C (HCV), and human immunodeficiency virus (HIV), but positive for HTLV-1. Due to the donor being asymptomatic, the sample was sent to hospital (King Fahad specialist hospital in Buraidah, Saudi Arabia), for confirmation.

The donor sample was screened for the presence of anti-HTLV-1 antibodies using chemiluminescent microparticle immunoassay (CMIA, Architect i2000SR Abbott Diagnostics, Abbott Park, IL, USA). Further confirmation was carried out using western blotting (Autoblot 3000, Bio-Rad Laboratories, Hercules, CA, USA). Complete blood count (CBC) was performed with a cell counter (Sysmex-KX-21TM, Japan). 
Table I. Complete blood count (CBC) prior to and after human T lymphotropic virus type-1 (HTLV-1) infection.

\begin{tabular}{|c|c|c|c|c|}
\hline \multirow{2}{*}{ Test } & \multirow{2}{*}{ Normal range } & \multirow{2}{*}{ Before infection } & \multicolumn{2}{|c|}{ After infection } \\
\hline & & & 0 month & 6 months \\
\hline $\mathrm{Hb}(\mathrm{g} / \mathrm{dL})$ & $12.9-14.2$ & 14.1 & 13.8 & 13.6 \\
\hline RBCs $\left(10^{6} / u L\right)$ & $4.06-4.69$ & 4.5 & 4.2 & 4.3 \\
\hline PLTS $\left(10^{3} / \mathrm{uL}\right)$ & $140-400$ & 260 & 250 & 270 \\
\hline \multirow{6}{*}{$\begin{array}{l}\text { WBCs }\left(10^{3} / \mathrm{uL}\right) \\
\text { NEU }(\%) \\
\text { LYM }(\%) \\
\text { MONO }(\%) \\
\text { ESO }(\%) \\
\text { BASO }(\%)\end{array}$} & $4.00-10.00$ & 5.5 & 8.5 & 7.9 \\
\hline & $1.63-6.96$ & 3.2 & 8.4 & 8.7 \\
\hline & $1.09-2.99$ & 1.6 & 6.2 & 6.6 \\
\hline & $.240-.790$ & .260 & .289 & .277 \\
\hline & $.030-440$ & .353 & .33 & .35 \\
\hline & $0.00-.080$ & .70 & .68 & .64 \\
\hline
\end{tabular}

Table II. Kidney, liver and heart enzymes prior to and after human T lymphotropic virus type-1 (HTLV-1) infection.

\begin{tabular}{|c|c|c|c|c|}
\hline \multirow{2}{*}{ Tests } & \multirow{2}{*}{ Normal range } & \multirow{2}{*}{ Before infection } & \multicolumn{2}{|c|}{ After infection } \\
\hline & & & 0 month & 6 months \\
\hline ALT (IU/L) & $<40$ & 30 & 35 & 32 \\
\hline AST (IU/L) & $<40$ & 29 & 28 & 27 \\
\hline Serum creatinine $(\mathrm{mg} / \mathrm{dL})$ & $0.7-1.3$ & 1.1 & 1.2 & 1.3 \\
\hline Serum urea $(\mathrm{mg} / \mathrm{dL})$ & $10-50$ & 45 & 42 & 39 \\
\hline Serum uric acid (mg/dL) & $2.1-8.5$ & 5.4 & 7 & 6.2 \\
\hline Serum ALP (U/L) & $38-126$ & 84 & 91 & 89 \\
\hline GGT (U/L) & $15-73$ & 66 & 76 & 73 \\
\hline Total bilirubin (mg/dL) & $0.1-1.3$ & 0.9 & 1.1 & 1.2 \\
\hline
\end{tabular}

Table III: Serum protein levels prior to and after infection with human T lymphotropic virus type-1(HTLV-1) infection.

\begin{tabular}{|l|c|c|c|c|}
\hline \multirow{2}{*}{ Test } & \multirow{2}{*}{ Normal range } & \multirow{2}{*}{ Before infection } & \multicolumn{2}{|c|}{ After infection } \\
\cline { 3 - 4 } & & 65 & 73 & $\mathbf{6}$ month \\
\hline Total protein $(\mathrm{g} / \mathrm{dL})$ & $34-52$ & 43 & 45 & 73.5 \\
Albumin $(\mathrm{g} / \mathrm{dL})$ & $18-36$ & 23 & 32 & 26 \\
Globulin $(\mathrm{g} / \mathrm{L})$ & & & 26 \\
\hline
\end{tabular}

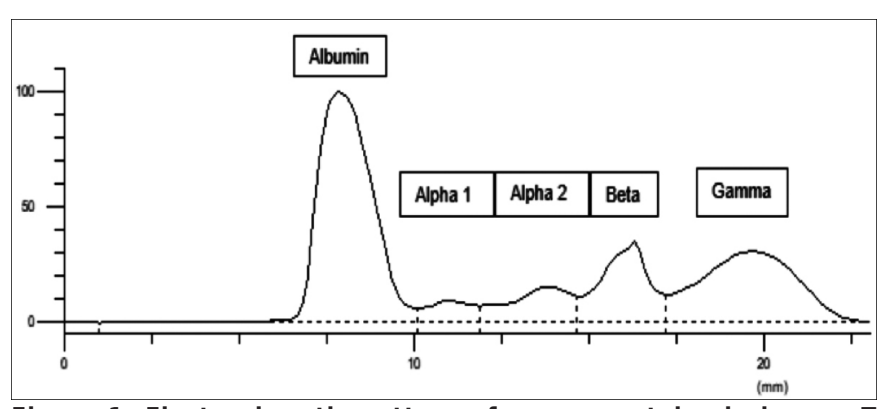

Figure 1: Electrophoretic pattern of serum proteins in human $T$ lymphotropic virus type-1 (HTLV-1) affected patient showing protein bands and the real area generated by Helena pro.

Biochemical tests to assess liver and kidney functions, cardiac enzymes and electrolytes, were performed with a full automated machine (Dimension Chemistry Analyser, USA). The serum protein levels in the blood sample were estimated using SAS-3 protein electrophoretic analysis (Helena Biosciences, Europe). The presence of HTLV-1 in the blood sample was confirmed using nucleic acid amplification testing (NAT). This donor as other donors that tested positive was permanently deferred from donating blood.

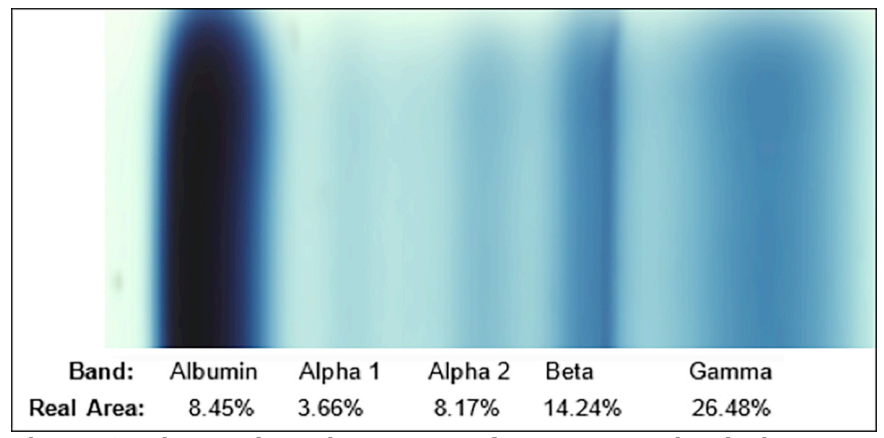

Figure 2: Electrophoretic pattern of serum proteins in human T lymphotropic virus type-1 (HTLV-1) infected patient generated by Helena programme.

Haematological and biochemical parameters were measured in this donor to observe any changes in their levels. The CBC was noted as normal except for levels of neutrophils and lymphocytes, which were high (Table I). Kidney and liver functions as well as cardiac enzyme levels were in the normal range (Table II). The donor appeared healthy and did not possess any physical abnormality. HTLV-1 virus screening was repeated, which confirmed the presence of HTLV-1; whereas, other viruses were not detected. Serum 
total protein levels were assessed during a routine check-up, which revealed acceptable levels (Table III). Moreover, serum proteins were analysed by SAS-3 protein electrophoretic analysis and the levels of alpha 1 and alpha 2, and beta and gamma globulins were found to be normal (Figures 1 and 2).

\section{DISCUSSION}

HTLV-1, a rare retrovirus in Saudi Arabia, can be transmitted through breast-feeding, sexual intercourse, or blood transfusion. It can easily be characterised by an oligo-clonal proliferative distribution pattern in asymptomatic hosts. It is not yet clear as to why only HTLV-1 causes T-cell malignancy. HTLV-1 is conclusively associated with a neoplasm, namely adult Tcell leukaemia/lymphoma (ATLL), which develops in approximately $5 \%$ of infected persons. A similar percentage of HTLV-1-infected individuals develop the neurological disease, $\mathrm{HAM} / \mathrm{TSP}{ }^{3}$

In the current case study, the patient looked healthy, as the reactive virus did not cause any signs or symptoms. Due to the low prevalence of the virus, treatment and healthcare processes for reactive donors are not yet established. The rare HTLV-1 case, presented in the current study, warrants periodic patient follow-ups to identify and control any signs or symptoms as early as possible.

Recently, a study was conducted to explore the protein changes in monocytes isolated from peripheral blood of asymptomatic carriers (AC), HAM/TSP and uninfected individuals using

Expression software. Approximately, 534 proteins were recognised; among which, 376 were quantified. Heat shock proteins and cytoskeleton proteins were found to be upregulated, while canonical histones were downregulated in monocytes of HTLV-1-infected individuals. ${ }^{9}$ However, there is no study available in the literature using the same markers as we used in the present study.

The findings of the current report show that the protein levels are close to the normal range and no much differences are observed in HTLV-1 carries compared to healthy individuals.

Studies have revealed that in many Arab countries, the HTLV-1 virus test is not frequently included in routine donor blood tests, which include HBsAg, HCV, HIV, and syphilis. It is imperative that prevalence rate of HTLV-1 should be determined in each country to protect people from contracting HTLV-1 infection.

Besides, advanced methods such as mass assisted laser desorption ionisation-time of fight (MALDI-TOF), flow cytometry, high performance liquid chromatography (HPLC) and microarrays should be used to investigate changes in protein levels to enable detection and control of this infection in its early stages.
Though HTLV-1 infection is rare in Saudi Arabia, it could prove fatal. Early detection and continuous follow-up of HTLV-1 infected patients is highly recommended, as in most cases, the virus is asymptomatic in the early stages. In addition, a comprehensive investigation at the protein and gene levels is highly recommended for HTLV-1-positive cases.

\section{PATIENT'S CONSENT:}

A written informed consent was obtained from the patient for participation in this study and to publish the data concerning in this case.

\section{CONFLICT OF INTEREST:}

Author has no conflict of interests.

\section{AUTHOR'S CONTRIBUTION:}

AAA: Conceptualization, methodology, investigation, analysis, writing and editing.

\section{REFERENCES}

1. Plummer M, de Martel C, Vignat J, Ferlay J, Bray F, Franceschi S. Global burden of cancers attributable to infections in 2012 a synthetic analysis. Lancet Glob Health 2016; 4(9): 609-16. doi: 10.1016/S2214-109X(16) 30143-7.

2. Gessain A, Cassar O. Epidemiological aspects and world distribution of HTLV-1 infection. Front Microbiol 2012; 3:388. doi: 10.3389/fmicb.2012.00388.

3. Ramalingam S, PrakashRKK, Ajithkumar K, Jacob M, George, R. A pilot study of HTLV-I infection in high-risk individuals. Indian J Med Res 2001; 113:200-09.

4. Arif M, Ramia S. Seroprevalence of human T-lymphotropic virus type I (HTLV-I) in Saudi Arabia. Ann Trop Med Parasitol 1998; 92(3):305-9. doi: 10.1080/0003498 9859870.

5. Hindawi S, Badawi M, Fouda F, Mallah B, Mallah B, Rajab H, Madani TA. Testing for HTLV 1 and HTLV 2 among blood donors in Western Saudi Arabia prevalence and cost considerations. Transfusion Med 2018; 28(1):60-4. doi: 10.1111/tme.12440.

6. Al-Mufti S, Voevodin A, Ahmed S, Al Hamdan S, AlBasheer AA. Seroprevalence of human T-Cell leukemia/Iymphoma virus type I and type II (HTLV-I/HTLV-II) infection among volunteer blood donors in Kuwait. Med Princ Pract 1999; 1:45-50. doi.org/10.1159/000026068.

7. Peters, AA, Coulthart MB, Oger JJ, Waters DJ, Crandall KA, Baumgartner AA. HTLV type $1 / I I$ in british columbia amerindians a seroprevalence study and sequence characterisation of an HTLV type Ila isolate. AIDS Res Hum Retroviruses 2000; 16(9):883-92. doi: 10.1089/088922 20050042828.

8. Alshehri A. Human T Lymphotropic virus-I (HTLV-I) the causative agent of acute t-cell leukaemia/lymphoma is absent among blood donors in aseer region-saudi arabia. J King Abdulaziz University-Science 2014; 148(3287): 
1-8. doi: 10.4197/Sci.26-1.3.

9. Echevarria-Lima J, de Abreu Pereira D, De Oliveira TS, de Melo Espíndola O, Lima MA, et al. Protein profile of blood monocytes is altered in HTLV-1 infected patients implications for HAM/TSP disease. Sci Rep 2018; 8(1): 14354. doi: 10.1038/s41598-018- 32324-2.

10. Amorim CF, Souza AS, Diniz AG, Carvalho NB, Santos SB $\&$ Carvalho E.M. Functional activity of monocytes and macrophages in HTLV-1 infected subjects. PLoS Negl Trop Dis 2014; 8(12):e3399. doi: 10.1371/journal.pntd.0003399. 